\title{
RESEARCH UPDATE
}

\section{Sudan and the Petrie Museum: Histories of Display, Scholarship and Engagement}

\author{
Anna Garnett
}

Of the 80,600 objects in UCL's Petrie Museum of Egyptian Archaeology, around 4000 are from Sudan. ${ }^{1}$ Flinders Petrie himself did not travel south of Aswan, and these items were acquired through different channels after his death. While many of these are on display in the Museum galleries-albeit tucked amongst the greater proportion of archaeological material from Egypt-much of the Sudanese collection remains in storage due to historic limitations of space. This paper presents an overview of the history of this collection, how it has inspired creative engagement projects targeting diverse museum audiences, and thoughts on future work.

\section{Anthony Arkell, Sudan and UCL}

The Petrie Museum's collection began to be extended with objects from excavations in Sudan during the tenure of Anthony J. Arkell (1898-1980) as Honorary Curator, which was only one role in his storied life (Figure 1). After a distinguished career in the Royal Flying Corps, Arkell joined the Sudan Political Service and subsequently became the first holder of the new post of Commissioner for Archaeology and Anthropology in 1939 (Ille 2018: 179; Smith 1981: 143). This position was part of the British colonial administration of Sudan prior to its independence from British and Egyptian governance, which took place on January 1st 1956. In this role, Arkell was tasked with setting up the Sudan National Museum (SNM) in Khartoum and documenting the museum's collection, with support from the British archaeologist Laurence P. Kirwan (Janssen 1992: 58; Siddiq

Petrie Museum of Egyptian Archaeology, UCL Culture, Malet PI, Bloomsbury, London, GB anna.garnett@ucl.ac.uk
Mohamed Gasm Elseed 2004: 10). During this vast project, Arkell worked with Sudanese

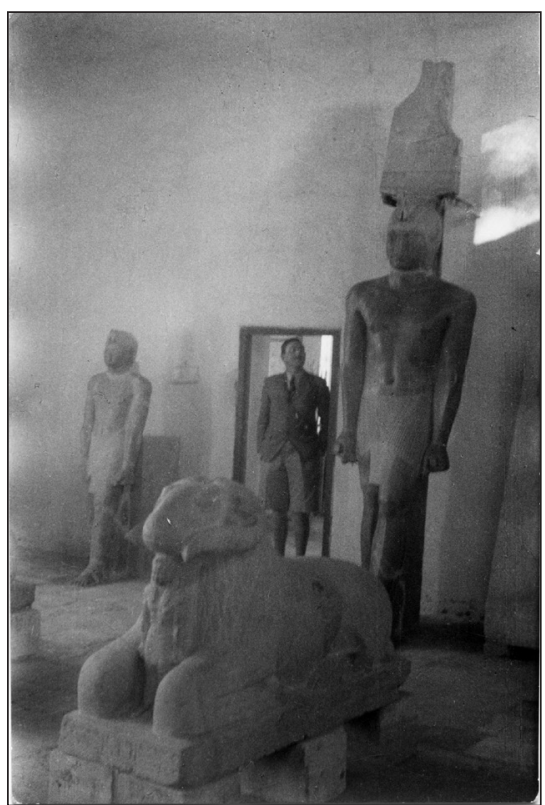

Figure 1: Anthony Arkell at Meroe (PORT. Arkell.01). Courtesy of The Egypt Exploration Society. 
students on object documentation and later appointed the first Sudanese inspectors to the newly-formed Sudan Antiquities Service, now the National Corporation for Antiquities and Museums (NCAM) (Smith 1981: 144). Alongside setting up the SNM, Arkell also supported Hilda Petrie to secure the donation of Petrie's working library to Khartoum after his death in 1942 (Drower 1995: 425). This collection, originally housed in a dedicated 'Flinders Petrie Library' building, comprised almost 1500 volumes, together with boxes of photographs and pamphlets, which subsequently formed the nucleus of the SNM library (Drower 1995: 425; Krol and Kuznezova 2014).

After the Second World War, Arkell led the first official excavations of the Sudan Antiquities Service at a Prehistoric site in the grounds of Khartoum Hospital (Arkell 1949; Edwards 2004: 24-26). Here, Arkell established the existence of a pottery-using culture associated with bone and stone tools which he characterised as Mesolithic (Arkell 1949: 111; Smith 1981: 144). From 1949-1950 Arkell then led excavations at Shaheinab, the site of an early Neolithic culture that he termed 'Khartoum Neolithic' (Arkell 1953a; Smith 1981: 145). Excavations revealed evidence for the domestication of sheep and goats, personal adornment including lip plugs, weapons and ceramics including Neolithic impressed and dotted wavy-line wares (Arkell 1953a: 102-108). Finds from these excavations were shared between UCL and SNM to promote teaching and research on Sudanese antiquity. In the 1950s, Martin Burgess, Petrie Museum Technician, made plaster cast sets of some of these objects which Arkell distributed to museums who wished to use them for teaching and display. Arkell's handwritten distribution list, and related correspondence, are kept in the Petrie Museum Archives. ${ }^{2}$

The then-Edwards Professor of Egyptian Archaeology and Philology at UCL, Jaroslav Černý, appointed Arkell as Lecturer in Egyptology and Honorary Curator in 1948 (Janssen 1992: 57-59; Růžová 2010). Until
Arkell's appointment, most of the Petrie Museum collection had remained in wartime storage in Foster Court. New 'temporary' museum accommodation had been identified above the Malet Place boiler houses and the task of systematically unpacking and documenting 800 crates of objects, and scrupulously checking excavation marks against British School of Archaeology in Egypt publications, fell to Arkell (Smith 1981: 146; Stevenson and Challis 2015: 19). Arkell obtained funds for suitable display cases, arranged preliminary conservation interventions for objects damaged in storage, and undertook measures to secure the building (Janssen 1992: 62-63; Smith 1981: 146). He also supervised the design of new-still extant-cupboards and wooden storage drawers, which are directly comparable with Arkell's design for the SNM stores in Khartoum (Figure 2). In 1953 the Petrie Museum celebrated the centenary of Flinders

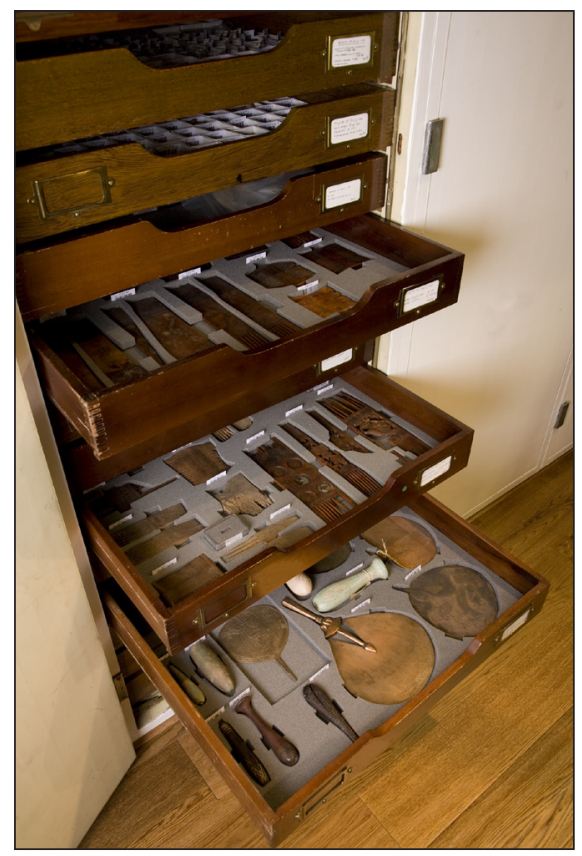

Figure 2: Petrie Museum storage system designed by Anthony Arkell (with modern object packing). Courtesy of the Petrie Museum of Egyptian Archaeology, UCL. 
Petrie's birth with a special exhibition, for which Arkell wrote the accompanying catalogue (Arkell 1953b; Janssen 1992: 64-69). By the time he retired from UCL in 1963 to become ordained, Arkell had succeeded to unpack and re-house the whole collection, and catalogue at least a third of it, over 14 years (Smith 1981: 146).

\section{Collection Histories: Donations and Display}

Sudanese objects, and objects associated with Sudan, were donated to the Petrie Museum during Arkell's term as Honorary Curator from 1948-1963. While in post, Arkell succeeded in forging meaningful links between UCL and the Sudan Antiquities Service, who presented a group of objects from sites including el-Kurru, Kerma, Meroe and Nuri to the Petrie Museum in 1955. This group includes 'tulip' beakers from Tumulus KIV at Kerma ${ }^{3}$ and inscribed stone shabtis from the royal pyramids at $\mathrm{Nuri}^{4}$ which remain popular with Petrie Museum visitors and hold special significance for African London audiences. The Museum also holds a small collection of Chinese pottery fragments which were collected at 'Aidhab, a port at the Egyptian-Sudanese border on the Red Sea, by Sir Douglas Newbold (1894-1945), colonial administrator for the British Empire in Sudan and Governor of Kordofan. They subsequently passed to Arkell, Newbold's friend and colleague, via Newbold's sister Kathleen Terry (Challis 2015: 92). Arkell registered the sherds into the collection where they remain, in storage, associated with Newbold's calling card. ${ }^{5}$ These sherds highlight trade relations between Africa, the Middle East and Asia during the $13^{\text {th }}-14^{\text {th }}$ centuries $A D$, as well as the political history of collecting in the early $20^{\text {th }}$ century (Challis 2015: 92).

The Petrie Museum retained around 1000 objects from the distribution of the Wellcome Collection in 1964, including more than 600 from excavations at Meroe led by John Garstang from 1909-1914 (Garstang 1911; Stevenson and Challis 2015: 19; Török 1997). Only a fraction of these objects are currently on display though several consistently feature in the 'Top 10' visitor trails: a faience votive ankh, inscribed with the name and epithets of Aspelta from Palace 294 at Meroe, is a particular visitor favourite (Chimbiri 2015: 94-95; Teasley, Quirke and Lacovara 2005: 104; Török 1997: 156, pl. 116). ${ }^{6}$ The Petrie Museum holds around 800 objects from Wellcome's own excavations at Jebel Moya from 1910-1914, together with the excavation reports kept in the Museum library (Addison 1949; Larson 2009: 58-59). Objects from Jebel Moya, including Neolithic lip plugs and stone armlets, feature alongside Kushite and Meroitic Sudanese objects in a Petrie Museum showcase. This display serves to highlight the richness of Sudanese material culture in the collection, but the nuances of their complex object histories are not currently evident to visitors due to their current sparse interpretation. During the 1960s, the Petrie Museum also received further donations of Sudanese material through the division of finds from the Egypt Exploration Society (EES) excavations at Buhen and Qasr Ibrim (Adams 2010; Emory, Millard and Smith 1979: 197-223). While fine painted Meroitic ceramics from Qasr Ibrim form eye-catching foci in the Pottery Gallery, these collections are otherwise currently under-represented in the Petrie Museum galleries due partly to their fragility.

\section{Creative Engagements with Sudan}

Over the past two decades Petrie Museum staff have led innovative creative engagement projects with Sudanese communities, and the Sudan collection. Of particular note is the MLA-Renaissance funded 'Hidden Histories' project (2007-2008), which aimed to create innovative points of public engagement with the collection through the direct involvement of Sudanese and Egyptian community groups (Helmy 2015: 2199). This project integrated conservation and curatorial knowledge with public engagement and new archaeological displays, focusing on the theme of personal adornment and the Petrie Museum's bead collection. As 
part of this project, various public-facing activities took place: notably, local Egyptian and Sudanese community members worked on the re-stringing of beads and provided reflective quotes on their experience and the collections for the project publication (Helmy and Nisbet 2008). An associated series of project lectures focused on complementary themes, including a presentation in Brixton delivered by the Director of the Nile Valley Museum in Aswan, Ossama Abdel Meguid, and hosted by the Sudanese Project Manager Rashid El-Sheikh, as part of Black History Month (Helmy 2015: 2215). In 2008, Sally-Ann Ashton (Fitzwilliam Museum, Cambridge) worked with Stephen Quirke to organise a series of free public workshops at the Fitzwilliam Museum, with the aim of providing community and student groups with the opportunity to raise important questions and issues with key African intellectuals relating to the ethnicity of ancient Egyptian and Sudanese people. Funded by the Heritage Lottery Fund, this project provided a platform for all participants to gain a stronger understanding of how Egypt fits into African cultural heritage in the modern day. Importantly, the project funding also enabled Ossama Abdel Meguid to travel to the UK to take part in these discussions.

In 2012, the leading Sudanese poet Al-Saddiq Al-Raddi participated in an Arts Council England-funded residency at the Petrie Museum, organised in association with the Poetry Translation Centre (PTC). Al-Raddi is widely regarded as one of the most important African poets writing in Arabic and his poetry frequently reflects on ancient Sudanese cultures (Al-Saddiq Al-Raddi 2015: 7-11). During his residency, organised by the late Sarah Maguire, PTC founder and Director, with Debbie Challis (Audience Development Officer), Al-Raddi worked closely with Stephen Quirke (Curator) to create a series of poems inspired by the Museum's collection of objects from Meroe (Al-Saddiq Al-Raddi 2015). This poetry collection, presented in English and Arabic, was subsequently nominated for The Ted
Hughes Award for New Work in Poetry and represents the culmination of an innovative, meaningful project which succeeded in its aim to creatively re-interpret the Museum's Sudanese collection.

\section{Future Directions}

The Petrie Museum's Sudanese collection has a rich, layered history which would significantly benefit from greater visibility through increased interpretation, to more effectively tease out the different object stories for visitors. The potential for further creative reinterpretation is also evident, particularly where this would include meaningful engagement with local Sudanese communities. The strong links between the Petrie Museum and the SNM-focusing on the similarities in object storage and documentation resulting from Arkell's vision for both museums-would repay deeper research and present opportunities for valuable reciprocal skills exchange between Petrie Museum and SNM staff, who share many of the same collections care-related issues. Ultimately, it is also clear that Sudan's role in the collection should be offered greater visibility: renaming the Museum as the Petrie Museum of Egyptian and Sudanese Archaeology would surely deliver that aim.

\section{Notes}

${ }^{1}$ For further information see the Petrie Museum's Online Catalogue (http://petriecat.museums.ucl.ac.uk/) and UCL Digital Egypt for Universities (https://www. ucl.ac.uk/museums-static/digitalegypt/ Welcome.html) [last accessed 20 March 2019].

2 PMA/WFP1/115/2/10.

${ }^{3}$ UC13214-5.

${ }^{4}$ UC13216-9.

${ }^{5}$ UC25796.

${ }^{6}$ UC43949.

\section{Acknowledgements}

This paper resulted from a presentation delivered for UCL Institute of Archaeology's 'Current Research in the Archaeology of 
Sudan' seminar series in February 2019. Grateful thanks are due to Claudia Näser, for inviting me as co-ordinator and speaker, to Stephen Quirke for his valuable feedback and fruitful discussions during my lecture, to Carl Graves and Stephanie Boonstra for pointing me towards the photograph of Arkell at Meroe, and to my dear NCAM colleagues for sharing their expertise and enthusiasm for Sudanese archaeology with me without hesitation or expectation.

\section{Competing Interests}

The author has no competing interests to declare.

\section{References}

Adams, W Y 2010 Qasr Ibrim: The Earlier Medieval Period. London: Egypt Exploration Society.

Addison, F 1949 Jebel Moya. London: Oxford University Press.

Al-Saddiq Al-Raddi 2015 He Tells Tales of Meroe: Poems for the Petrie Museum. London: Rubine Press. DOI: https://doi. org/10.2307/j.ctt1g69z2n.38

Arkell, A J 1949 Early Khartoum: An Account of the Excavation of an Early Occupation Site carried out by the Sudan Government Antiquities Service in 1944-5. London: Oxford University Press.

Arkell, A J 1953a Shaheinab: An Account of the Excavation of a Neolithic Occupation Site carried out for the Sudan Antiquities Service in 1949-50. London: Oxford University Press.

Arkell, A J 1953b Flinders Petrie Centenary Exhibition Catalogue. London: University College London.

Challis, D 2015 From China to Sudan. In: Stevenson, A (ed.), The Petrie Museum of Egyptian Archaeology: Characters and Collections. London: UCL Press. pp. 92-93. DOI: https://doi.org/10.2307/j. ctt1g69z2n.36

Chimbiri, K 2015 The ancient Kushite city of Meroe. In: Stevenson, A (ed.), The Petrie Museum of Egyptian Archaeology: Characters and Collections. London:
UCL Press. pp. 94-95. DOI: https://doi. org/10.2307/j.ctt1g69z2n.37

Drower, M S 1995 Flinders Petrie: A Life in Archaeology (2 ${ }^{\text {nd }}$ Edn.). London, Wisconsin: University of Wisconsin Press.

Edwards, D N 2004 The Nubian Past: An Archaeology of the Sudan. London: Routledge. DOI: https://doi. org/10.4324/9780203482766

Emory, W B, Millard, A and Smith, H S 1979 The Fortress of Buhen: The Archaeological Report. London: Egypt Exploration Society.

Garstang, J 1911 Meroë the City of the Ethiopians: being an Account of a First Season's Excavations on the Site, 1909-1910. Oxford: Clarendon Press.

Helmy, M 2015 Hidden Histories Project at the Petrie Museum of Egyptian Archaeology. In: Kousoulis, $\mathrm{P}$ and Lazaridis, $\mathrm{N}$ (eds.) Proceedings of the Tenth International Congress of Egyptologists, University of the Aegean, Rhodes, 22-29 May 2008. Leuven: Peeters. pp. 2199-2216.

Helmy, M and Nisbet, E 2008 Hidden Histories Exhibition Catalogue. London: Petrie Museum.

Ille, E 2018 Anthony John Arkell as Commissioner for Archaeology and Anthropology (1939-1948). A look into an early experiment with Interdisciplinary Administration. Sudan \& Nubia, 22: 179-187.

Janssen, R M 1992 The First Hundred Years: Egyptology at University College London 1892-1992. Surrey: Laws and Stimson Associates.

Krol, A and Kuznezova, A 2014 Photographic Memory. Photoarchive of W.M.F. Petrie from the National Museum of Sudan. Moscow: CESRAS [in Russian].

Larson, F 2009 An Infinity of Things: How Sir Henry Wellcome Collected the World. Oxford: Oxford University Press.

Růžová, J 2010 The Scribe of the Place of Truth: The Life of the Egyptologist Jaroslav Černý. Prague: Nakladatelství Libri. 
Siddiq Mohamed Gasm Elseed 2004 Sudan National Museum, Past and Present. In: Welsby, D A and Anderson, J R (eds.) Sudan, Ancient Treasures: An Exhibition of Recent Discoveries from the Sudan National Museum. London: British Museum Press. pp. 10-11.

Smith, H S 1981 The Reverend Dr. Anthony J. Arkell. Journal of Egyptian Archaeology, 67: 143-148. DOI: https://doi. org/10.1177/030751338106700113

Stevenson, A and Challis, D 2015 Introduction: A Modest Little Museum. In: Stevenson, A (ed.) The Petrie Museum of Egyptian Archaeology: Characters and Collections. London: UCL Press. pp. 11-25. DOI: https://doi.org/10.2307/j. ctt1g69z2n.7

Teasley, B T Quirke, S and Lacovara, P 2005 Excavating Egypt: Great Discoveries from the Petrie Museum of Egyptian Archaeology, University College London. Atlanta: Michael C. Carlos Museum.

Török, L. 1997 Meroe City, an Ancient African Capital: John Garstang's Excavations in the Sudan. London: Egypt Exploration Society.

How to cite this article: Garnett, A 2019 Sudan and the Petrie Museum: Histories of Display, Scholarship and Engagement. Archaeology International, 22(1), pp. 66-71. DOI: https://doi.org/10.5334/ ai-400

Submitted: 31 March 2019

Accepted: 12 November 2019

Published: 17 January 2020

Copyright: (c) 2019 The Author(s). This is an open-access article distributed under the terms of the Creative Commons Attribution 4.0 International License (CC-BY 4.0), which permits unrestricted use, distribution, and reproduction in any medium, provided the original author and source are credited. See http://creativecommons.org/licenses/by/4.0/.

] $\mathbf{u}[$ Archaeology International is a peer-reviewed open access journal published by Ubiquity Press. 